https://doi.org/10.21272/mmi.2021.3-13 JEL Classification: D23, Q40, Q48, Q43, L94

Ihor Vakulenko,

Ph.D., Sumy State University, Ukraine

D ORCID ID, 0000-0002-6994-833X

email: vakulenko@ms.sumdu.edu.ua

Maksym Fritsak,

Swiss Federal Institute of Technology Zurich, Germany

email:mfritsak@student.ethz.ch

Pavlo Fisunenko,

Ph.D., Prydniprovs'ka State Academy of Civil Engineering, Ukraine

ORCID ID, 0000-0002-1339-5860

email: fisunenko.pavlo@pgasa.dp.ua

Correspondence author:vakulenko@ms.sumdu.edu.ua

\title{
AN ORGANIZATIONAL SCHEME FOR SCALING INNOVATIVE ENERGY PROJECTS. SMART GRIDS CASE
}

Abstract. The transition to a carbon-neutral economy, which is now taking place in many countries, requires the use of profound transformations in energy, including the use of innovative technologies. Smart grids are the embodiment of innovative energy development. They involve the widespread use of modern advanced technologies in many areas, from energy production to designing a secure information system. Successful local projects need help to spread them globally. However, such assistance should not be limited to government intervention and administrative methods. A self-regulatory market mechanism is required to scale such projects. Some countries have a well-trodden path for innovation. However, the speed of innovation differs in each country. It depends on many unique conditions that exist in a country. There is hardly a one-size-fits-all way to spread innovation quickly that will be good for every country. However, there must be a mechanism where all stakeholders work organized to spread innovation, which accelerates this process. This article proposes an approach to developing a stakeholder interaction scheme to implement innovative projects in the energy sector based on the smart grid maturity model. To achieve this goal, the results of a comparative analysis of smart grids' comprehensive assessment systems were used, which allowed algorithmizing the processes of their creation, development, and maintenance as a basis for further scaling successful projects. The defined algorithm is a modification of the smart grid maturity model developed by IBM. In addition, a thorough analysis of scientific publications in the field of innovative projects in the energy sector is dedicated to introducing smart grids. The visualization of the proposed approach to streamlining the activities of stakeholders is based on the results of a study aimed at finding ways to overcome organizational and communication barriers between stakeholders, where the coding of the processes of smart grid projects. The scientific results presented in this article are an intermediate stage in the study of mechanisms to improve the efficiency of implementation and scaling of innovative energy-efficient projects, particularly the development of smart grids, based on the activation of latent drivers. Such drivers are organizational and communication tools.

Keywords: organizational scheme, energy, smart grids, stakeholders, maturity model.

Introduction. Modern research often raises the topic of stakeholder interaction because it is essential to finding optimal ways to implement projects that will increase resource use efficiency and reduce the time from project development to its implementation. Organizational approaches are a valuable management tool because they activate the hidden reserves of project implementation. Projects differ in the degree of uniqueness, from the so-called standard projects to unique. It makes it challenging to manage them. In addition, the industry in which the project is implemented is also important. Mechanisms used in one industry may not be suitable for use in another.

Cite as: Vakulenko, I., Fritsak, M., Fisunenko, P. (2021). An Organizational Scheme for Scaling Innovative Energy Projects. Smart Grids Case. Marketing and Management of Innovations, 3, 149-164. http://doi.org/10.21272/mmi.2021.3-13 
It is necessary to determine the optimal approaches applied in a particular economic sector to implement much in common projects. This article examines the interaction of stakeholders in the implementation and support of smart grid projects.

The relevance of the research topic is that smart grids are an unalterable direction in the development of electricity. In a few decades, and perhaps even earlier, when talking about smart grids, they will use the term power grids without mentioning them as smart. After all, by that time, they will become traditional. And power grids, which are considered classic now, will be regarded as outdated and inefficient.

Smart grids are a progressive approach to building a carbon-neutral economy that meets modern challenges and climate policy elements. The combination of automation, digitalization, and distributed energy generation based on the large-scale use of renewable energy sources allow achieving a significant number of environmental, social, and economic goals to implement sustainable development policies.

The COVID-19 pandemic has contributed to the vision of smart grid development. The change in energy consumption profiles and the consequent need to take a more flexible approach to energy production has proven the need for the rapid growth of smart grids.

The importance of the research area is obvious, given the systemic policies to support the development of smart grids in many countries worldwide. A successful example of such a policy is the countries of the European Union, where many smart grid projects are being systematically implemented. However, the question is whether the available resources are used efficiently enough to develop smart grids. Can the pace of their development be higher than available at a given amount of resources, including financial, which are spent now? What conditions need to be created to scale innovative energy projects of smart grids faster? Who should be involved in this process, and what mechanisms should be applied? The answer to these questions allows us to propose a stakeholder engagement scheme to accelerate the implementation and scaling of innovative energy projects. The study uses theoretical approaches and analyses of existing experience in implementing smart grids.

Literature Review. The relationship between the achievement of climate policy goals and the introduction of modern innovative technologies in energy, in particular, the development of renewable energy, is discussed in the studies of Fotis P. and Polemis M. (2018), Mentel G., Vasilyeva T., Samusevych Y., Vysochyna A., Karbach R. and Streimikis, J. (2020), Hilorme T., Sokolova L., Portna O., Lysiak L. and Boretskaya N. (2019). It requires to focus activities on coordinating the efforts of stakeholders to disseminate successful experiences and the formation of profitable business models. It requires a mechanism for making strategic decisions to support innovative projects (Tetiana $\mathrm{H}$. and Chernysh 0 ., 2019; Chygryn O. and Pimonenko, 2018).

Späth L. and Scolobig A. (2017) consider how to involve stakeholders in energy projects to decarbonize the economy by expanding their rights and opportunities. At the same time, German researchers Gölz S. and Wedderhoff O. (2018) emphasize the importance of acceptance by stakeholders, including the population (Graff M. and Carley S., 2018; Sun Y. and Li Y., 2020), paradigms of modern energy development. Stakeholder satisfaction is increasingly seen as one of the critical factors in the success of renewable energy projects (Maqbool R. and Deng X., 2020). It should help to overcome barriers (Nasr A.K. and Kashan M.K., 2020), Vakulenko I. and Saher L., 2021) and the resistance of stakeholders, which leads to a slowdown in energy reform, despite the social significance of this process. Some scientists are proposing approaches that rethink the role of stakeholders in building an environmentally sound energy system. In particular, Olkkonen L., Korjonen-Kuusipuro K. and Grönberg I. (2017) support this approach.

The study by Dias L. C., Antunes C. H., Dantas G., de Castro N. and Zamboni L. (2018) systematizes the processes and interaction of stakeholders in creating smart grids. Noteworthy is a similar study by Neves D., Baptista P., Simões M., Silva C. A. and Figueira J. R. (2018), which focuses on multi-criteria modeling of decision-making by government institutions when planning a strategy for energy network 
development. Stakeholders should take an active part in this process, along with the authorities (Baldwin E., 2019; Ouhajjou N. and Loibl W., 2017; Danielson M. and Ekenberg L., 2018). In particular, they should determine indicators for assessing the effectiveness of energy policy (Gunnarsdóttir I. and Davíðsdóttir B., 2021). In Ukraine, research on similar topics is carried out by Hilorme T. and Tkach K., Dorenskyi O., Katerna O. and Durmanov A. (2019). Notably, the scale of innovation, particularly in the energy sector, depends significantly on how well the cooperation between local authorities and stakeholders is established (Bourdin S. and Nadou F., 2019). Valuable research is Afshari H., Farel R., Peng Q. (2018), where design models stakeholders' cooperation in creating industrial parks, which will promote intersectoral and territorial dissemination of innovation. Approaches to the study of this issue differ significantly, in particular, Chinese scientists Gao L., Zhao Z. (2020) use game theory in their research, and a group of researchers from Iceland and the United Kingdom (Guðlaugsson B. and Fazeli R., 2020) use in their study work a two-dimensional power-interest matrix and fuzzy logic.

However, in stakeholder collaboration and modeling their interaction, it is essential not to overlook the fact that it is appropriate to add stakeholders from related areas to this model. This opinion is investigated by White D. D., Jones J. L., Maciejewski R., Aggarwal R., Mascaro G. (2017), Sušnik J., Chew C., Domingo X., Mereu S., Trabucco A. et al (2018), Hoolohan C., Larkin A., McLachlan C., Falconer R., Soutar I., Suckling J. et al. (2018). It will help to develop both energy and related sectors of the economy. In addition, it will allow achieving goals more effectively in associated areas, in particular, climate and security (Vysochyna A. and Stoyanets N., 2020; Vasylieva T. and Lyulyov 0., 2019).

An essential issue in the implementation of energy policy, the introduction of energy innovations, in particular, through the creation and development of smart grids is the assessment of the risks of stakeholders involved in these processes (Jia L. and Qian, Q.K., 2020). Macroeconomic dynamic stochastic general equilibrium model and a business strategy assessment model are used by (Nikas A. et al, 2020; Nikas A., Stavrakas V., 2020). The use of social responsibility as one of the levers for changing the behavior of stakeholders is explored by Ehsan S., Nazir M. S., Nurunnabi M., Khan Q. R., Tahir S., Ahmed I. (2018). The formation of mandatory reporting requirements for enterprises, organizations, and institutions can also positively impact this case (Tang S., Demeritt, D., 2018).

Several studies focus on the narrow areas of development of a sustainable model of the energy system and the introduction of individual components of smart grids. In particular, the research of Liu H., You X., Xue Y., Luan X. (2017) examines the interaction of stakeholders in stimulating the electric vehicle market on the example of China. Instead, Li H. X., Patel D., Al-Hussein M., Yu H., Gül M. (2018), Adinyira E., Kwofie T. E., Quarcoo F. (2018)) and Zedan S., Miller W. (2018) research stakeholders cooperation during the construction of NetZero Energy Homes. Also, NetZero houses investigate in paper by Pimonenko T., Prokopenko O., Dado J. (2017). At the same time, the study of Joensuu T., Norvasuo M., Edelman H. (2020) focuses on the creation of housing estates on this principle. The research by Elmustapha H., Hoppe T., Bressers H. (2018) analyzes the views of stakeholders and the impact of the socio-cultural dimension on the introduction of solar energy technology. Solman H., Smits M., van Vliet B., Bush S. (2021) and Curtis P. G., Hanias M., Kourtis E., Kourtis M. (2020) studies issues of stakeholder cooperation in wind energy. Instead, Alvial-Palavicino C., Garrido-Echeverría N., Jiménez-Estévez G., Reyes L., PalmaBehnke R. (2011) study the involvement of stakeholders in the creation of microgrids based on renewable energy sources.

Methodology and research methods. This study is based on the logical and structural analysis of smart grid projects' development, implementation, and maintenance processes, directly or indirectly provided by the existing smart grid's comprehensive assessment systems.

In the course of the research, the following comprehensive assessment systems are analyzed:

- IBM Smart Grid Maturity Model, IBM,

- DOE Smart Grid Development Evaluation System, DOE, 
- EPRI Smart Grid Construction Assessment Indicators, EPRI,

- EU Smart Grid Assessment Benefits Systems, EUA,

- "Two Type" grid index system, TTS,

- Grid development assessment index system, GDA,

- Smart grid pilot project evaluation indicator system, PPE,

- Evaluation Model of a Smart Grid Development Level Based on Differentiation of Development Demand, DDD.

The purpose of the initial analysis of assessment systems is to identify the processes they evaluate. Since each system estimates smart grids in several areas, it is possible to identify a set of measures (or processes) whose implementation is necessary for successful planning, implementation, and maintenance of a smart grid project.

Most comprehensive assessment systems do not indicate the processes that need to be carried out to implement smart grids and their maintenance after launch successfully. These assessment systems contain a set of indicators that need to be calculated to characterize a smart grid's efficiency. Significant differences in approaches to evaluation were taken into account at the stage of their structural analysis. After all, the differences between evaluation approaches make it necessary first to streamline evaluation approaches and then use them to determine how stakeholders will be involved in the planning, implementation, and development of smart grids. To this end, all indicators of comprehensive assessment systems should be divided into universal groups and cover a significant number of effects caused by the operation of a smart grid. This approach allows for the identification of all critical processes during the development of smart grids. In addition, it is possible to compare systems to see how comprehensively they evaluate smart grids. It creates opportunities to combine the advantages of individual comprehensive assessment systems, eliminating the inherent gaps in each of them.

Some systems contain an algorithm that implements smart grid projects. The IBM Smart Grid Maturity Model is a complete algorithm among the studied evaluation systems. This research uses IBM Smart Grid Maturity to build an organizational scheme of interaction of stakeholders during the development of smart grids. Other systems have complemented the set of smart grid development processes by filling in the gaps in the IBM Smart Grid Maturity Model.

Visualization of the results of the formation of the organizational scheme of stakeholder interaction required the coding of the processes identified during the analysis. It was done at the stage preceding the shape of the organizational scheme.

Results. A systematic approach to the development of smart grids involves using a wide range of tools to regulate the activities of stakeholders and direct participants in smart grids projects.

It is necessary to systematize the interaction of stakeholders to intensify the development of projects, their implementation, and scaling to the national economy level. It required developing an organizational and communication scheme of stakeholder interaction has been.

The proposed in this paper scheme is different from the existing approaches to the organization of stakeholder interaction. Because it comprehensively covers the set of relationships between stakeholders in the implementation, support and maintenance, and development of smart grids, and includes the following components:

- strategy and regulation,

- technologies,

- organization,

- social factors

- environmental impact,

- network operations,

- integration of value chains, 
- asset management

- interaction with clients, and knowledge management.

This approach allows us to identify problematic aspects of stakeholder interaction that hinder the development of smart grids and identify mechanisms for regulating stakeholder relations in deploying smart grids. As a result, the construction of a stakeholder interaction scheme and the formation and maintenance of instruments for its implementation can be seen as a tool to use the hidden potential for developing smart grids. A scheme of stakeholder interaction is proposed to reconcile their interests, identify and eliminate antagonism in their behavioral patterns, break down barriers during stakeholder interaction, and level the causes of intrasystem and external conflicts. The formation of a stakeholder interaction system based on the organizational and communication scheme of their interaction allows to identify and formalize the most effective mechanisms of regulatory interventions to regulate stakeholder relations in the process of implementing smart grids and take into account latent effects and drivers (European Technology Platform Smart Grids, 2020; Kester J., 2016; Lieonov S. and Pavlyk A., 2019). The relevance of this task is confirmed by the presence of thorough research aimed at solving this problem (Hilorme T. and Nazarenko I., 2018). The basis of the developed stakeholder interaction scheme is the maturity model of the IBM smart grid. The choice of this model is justified by the results of a comparative analysis of smart grid assessment systems (Lyulyov O. and Vakulenko 2021)). The analysis results show that IBM's smart grid maturity model contains the smart grid projects implementation algorithm. This assessment system has indicators at each stage of smart grid design and implementation. This paper modified the IBM smart grid maturity model, including different processes not provided by the original model, which IBM developed in collaboration with other companies. It is necessary to consider stakeholders' interaction in smart grids better.

Similar to the original IBM smart grid maturity model, the proposed scheme provides the following levels of smart grid projects implementation: Preparation (level 0); Exploring and Initiating (level 1); Investing (level 2); Integrating (level 3); Optimizing (level 4); Innovating (level 5).

According to the IBM smart grid maturity model modification, the list of operations (processes, goals, and results) is located in the paper published by Vakulenko I., Saher L., Syhyda L., Kolosok S., Yevdokymova A. (2021)). Coding was applied to these processes. This research is based on results published by Vakulenko I., Saher L., Syhyda L., Kolosok S., Yevdokymova A. (2021) on the first step in breaking barriers between stakeholders and continues that paper. Applied coding combines smart grid projects developing processes and enhanced stakeholders. For instance, A2 means the stakeholder with code "2" is involved in process "A"; 2B3 implies that stakeholder "3" is involved in the process "2B". Stakeholders and their codes (in brackets) are following: Project initiator (1), Public authorities or state government (2), Local authorities (3), International institutions (4), Project executor (5), Public, nongovernmental organizations, including international (6), Research institutions (7), Project organizations (8), Financial and credit organizations (9), Market regulator (10), Project customer (11), Gen/Load Wholesalers (12), Wholesale Market Operators (13), Transmission Providers (14), Energy Service Retailers (15), Distribution providers (16), End-Users: Industrial, Commercial, Residential (17), Supporting organizations: product and service suppliers (18), Shareholders (19), Territorial community, population (20). The results of structuring the interaction of stakeholders were endpoint in the paper Vakulenko I., Saher L., Syhyda L., Kolosok S., Yevdokymova A. (2021). Table 1 and Table 2 shows these results. But this research is built on structuring the interaction of stakeholders.

All processes in the smart grid maturity model could be divided into two groups. Table 1 shows the processes required for designing a smart grid.

Table 2 shows the processes required for developing and scaling smart grids projects.

Because the matrix of stakeholder interaction included a significant number of processes occurring at different stages of energy efficiency and energy modernization projects through the introduction of 
l., Vakulenko, M., Fritsak, P. Fisunenko. An Organizational Scheme for Scaling Innovative Energy Projects. Smart Grids Case

innovative and environment-friendly energy technologies, the processes that have the most significant impact on implementation were identified.

Table 1. Processes of the stakeholders' interaction in the pre-integration stages of creating a smart grid

\begin{tabular}{|c|c|c|c|c|c|c|c|c|c|}
\hline & $\begin{array}{l}\text { The Smart } \\
\text { Grid } \\
\text { Maturity } \\
\text { Model Level }\end{array}$ & $\begin{array}{c}\text { Strategy, } \\
\text { Management } \\
\text { \& Regulatory }\end{array}$ & $\begin{array}{l}\text { Organization } \\
\text { \& Structure }\end{array}$ & Technology & $\begin{array}{c}\text { Societal \& } \\
\text { Environmen } \\
\text { tal }\end{array}$ & $\begin{array}{c}\text { Grid } \\
\text { Operations }\end{array}$ & $\begin{array}{c}\text { Work \& } \\
\text { Asset } \\
\text { Management }\end{array}$ & $\begin{array}{c}\text { Customer } \\
\text { Management } \\
\& \\
\text { Experience }\end{array}$ & $\begin{array}{c}\text { Value } \\
\text { Chain } \\
\text { Integration }\end{array}$ \\
\hline 2 & $\begin{array}{l}\text { Functional } \\
\text { Investing }\end{array}$ & $\begin{array}{l}\text { E1*, E5, E9, } \\
\text { E11, F2, F3, } \\
\text { F4*, F5, F8, } \\
\text { F9, F11, G9, } \\
\text { G5, G11 }\end{array}$ & $\begin{array}{l}\text { R5, R8, R11, } \\
\text { S2, S5, S11, }\end{array}$ & $\begin{array}{l}\text { 2B9, 2B11, } \\
\text { 2C10-17, } \\
\text { 2D5, 2D11, } \\
3 Z 5,3 Z 7-8, \\
3 Z 11-18\end{array}$ & $\begin{array}{l}2011,2017, \\
2018\end{array}$ & $\begin{array}{l}\text { 3B5, 3B9, } \\
\text { 3B10, 3B11, } \\
\text { 3B18 }\end{array}$ & $\begin{array}{l}315,318,3111, \\
3118\end{array}$ & $\begin{array}{l}\text { 3N5, 3N8, } \\
\text { 3N11, 3N17, } \\
\text { 3N18, 305, } \\
307-9,3011\end{array}$ & $\begin{array}{l}3 \times 5,3 X 7, \\
3 \times 8,3 \times 11, \\
3 \times 17, \\
3 X 18,3 Y 5, \\
3 Y 7,3 Y 11\end{array}$ \\
\hline 1 & $\begin{array}{l}\text { Exploring } \\
\text { and } \\
\text { Initiating }\end{array}$ & $\begin{array}{l}\text { A2, A3, A4*, } \\
\text { A6, A7, B1*, } \\
\text { B5, B7, B8, } \\
\text { B11, C1, C2, } \\
\text { C3, C5, C8, } \\
\text { C10, C11, } \\
\text { D1, D5, D8, } \\
\text { D9, D11 }\end{array}$ & $\begin{array}{l}\text { O2, O3, O4*, } \\
\text { O10, P6-8, } \\
\text { P11, P17, } \\
\text { Q7, Q8, Q11 }\end{array}$ & $\begin{array}{l}Y 7, Y 18, Z 7, \\
2 A 5,2 A 7, \\
2 A 11,2 A 18\end{array}$ & $\begin{array}{l}2 \mathrm{M} 2,2 \mathrm{M} 3, \\
2 \mathrm{M} 6,2 \mathrm{M} 7, \\
2 \mathrm{M} 17,2 \mathrm{M} 19, \\
2 \mathrm{M} 20,2 \mathrm{~N} 11, \\
2 \mathrm{~N} 17,2 \mathrm{~N} 18, \\
3 \mathrm{Y} 1,3 \mathrm{Y} 2^{*}, \\
3 \mathrm{Y} 3^{*}, 3 \mathrm{Y} 7, \\
3 \mathrm{Y} 11,3 \mathrm{Y} 17\end{array}$ & $\begin{array}{l}2 \mathrm{Y} 5,2 \mathrm{Y} 7, \\
2 \mathrm{Y} 11,2 \mathrm{Y} 18, \\
2 \mathrm{Z} 5,2 \mathrm{Z}, \\
2 \mathrm{Z} 11,2 \mathrm{Z} 18, \\
3 \mathrm{~A} 5,3 \mathrm{~A} 11\end{array}$ & $\begin{array}{l}3 \mathrm{G} 5,3 \mathrm{G} 7-9, \\
3 \mathrm{G} 11,3 \mathrm{H} 5 \\
3 \mathrm{H} 7-9,3 \mathrm{H} 11\end{array}$ & $\begin{array}{l}\text { 3M6-8, 3M11, } \\
\text { 3M17 }\end{array}$ & $\begin{array}{l}3 \mathrm{~V} 5,3 \mathrm{~V} 6^{*}, \\
3 \mathrm{~V} 7-9, \\
3 \mathrm{~V} 11-17, \\
3 \mathrm{~V} 20^{*}, \\
3 \mathrm{~W} 7,3 \mathrm{~W} 9, \\
3 \mathrm{~W} 11,3 \mathrm{Z} 9, \\
\text { 3Z11 }\end{array}$ \\
\hline 0 & $\begin{array}{l}\text { Default } \\
\text { level } \\
\text { (status } \\
\text { quo) }\end{array}$ & $\begin{array}{l}\text { A2, A3, A4*, } \\
A 6, A 7\end{array}$ & & & & & & & \\
\hline
\end{tabular}

Sources: (Vakulenko I. and Saher L., 2021)

Table 2. Processes of stakeholder interaction at the integration and optimization stages of creating a smart grid

\begin{tabular}{|c|c|c|c|c|c|c|c|c|c|}
\hline \multicolumn{2}{|c|}{$\begin{array}{c}\text { The Smart Grid } \\
\text { Maturity Model } \\
\text { Level }\end{array}$} & $\begin{array}{c}\text { Strategy, } \\
\text { Manage- } \\
\text { ment \& } \\
\text { Regulatory }\end{array}$ & \multirow{2}{*}{$\begin{array}{c}\begin{array}{c}\text { Organiza- } \\
\text { tion \& } \\
\text { Structure }\end{array} \\
\text { X1-4, X6- } \\
19 \\
\end{array}$} & \multirow{2}{*}{$\begin{array}{l}\text { Technology } \\
\begin{array}{l}\text { 2L7, 2L11- } \\
18\end{array}\end{array}$} & \multirow{2}{*}{$\begin{array}{c}\begin{array}{c}\text { Societal \& } \\
\text { Environmental }\end{array} \\
2 \mathrm{~W} 11,2 \mathrm{~W} 17, \\
2 \mathrm{~W} 18,2 \mathrm{X} 10, \\
2 \mathrm{X} 11,2 \mathrm{X} 12-18\end{array}$} & \multirow{2}{*}{$\begin{array}{c}\begin{array}{c}\text { Grid } \\
\text { Operations }\end{array} \\
\text { 3F2, 3F10, } \\
\text { 3F11, 3F18 }\end{array}$} & \multirow{2}{*}{$\begin{array}{l}\begin{array}{c}\text { Work \& } \\
\text { Asset } \\
\text { Management }\end{array} \\
3 \mathrm{~L} 11,3 \mathrm{~L} 10- \\
18\end{array}$} & \multirow{2}{*}{$\begin{array}{l}\begin{array}{c}\text { Customer } \\
\text { Management } \\
\begin{array}{c}\& \\
\text { Experience }\end{array}\end{array} \\
3 \mathrm{~T} 11-17, \\
3 \mathrm{U} 2,3 \mathrm{U} 4^{*}, \\
3 \mathrm{U} 6,3 \mathrm{U} 10, \\
3 \mathrm{U} 11,3 \mathrm{U} 17, \\
3 \mathrm{U} 18\end{array}$} & \multirow{2}{*}{$\begin{array}{l}\begin{array}{c}\text { Value } \\
\text { Chain } \\
\text { Integration }\end{array} \\
4 \mathrm{~F} 9-18, \\
4 \mathrm{G} 3,4 \mathrm{G} 10- \\
17,4 \mathrm{Q} 11- \\
16\end{array}$} \\
\hline 5 & $\begin{array}{l}\text { Innovating - } \\
\text { Next Wave of } \\
\text { Improvements }\end{array}$ & $\begin{array}{l}\text { N2, N10, } \\
\text { N11, N12- } \\
\text { 16, 4011, } \\
\text { 4019, 4P2- } \\
3,4 \mathrm{P} 4^{*}, \\
4 \mathrm{P} 10\end{array}$ & & & & & & & \\
\hline 4 & $\begin{array}{l}\text { Optimizing - } \\
\text { Enterprise- } \\
\text { Wide }\end{array}$ & $\begin{array}{l}\text { L11, M2*, } \\
\text { M3, M4*, } \\
\text { M6*, M7-10, } \\
\text { M12-19, }\end{array}$ & $\begin{array}{l}\text { V2, V3, } \\
\text { V4* V6*, } \\
\text { V9, V11- } \\
\text { V19, W11 }\end{array}$ & $\begin{array}{l}2 \mathrm{H} 11,2 \mathrm{l} 11- \\
18,2 \mathrm{~J} 7 \\
2 \mathrm{~J} 11,2 \mathrm{~K} 7 \\
2 \mathrm{~K} 18\end{array}$ & $\begin{array}{l}2 \mathrm{R} 2,2 \mathrm{R} 3, \\
2 \mathrm{R} 4^{*}, 2 \mathrm{R} 6-18, \\
2 \mathrm{~S} 2,2 \mathrm{~S} 3,2 \mathrm{~S} 4, \\
2 \mathrm{~S} 9,2 \mathrm{~S} 11, \\
2 \mathrm{~T} 2,2 \mathrm{~T} 3,2 \mathrm{~T} 4^{*}, \\
\mathrm{~T} 6,2 \mathrm{~T} 10, \\
2 \mathrm{~T} 19,2 \mathrm{U} 11-17, \\
2 \mathrm{~V} 11-12, \\
2 \mathrm{~V} 14-17\end{array}$ & 3E11 & $\begin{array}{l}\text { 3K11, 3K17, } \\
\text { 3K18 }\end{array}$ & $\begin{array}{l}\text { 3S11-18, } \\
\text { 4D2, 4D3, } \\
\text { 4D10-17 }\end{array}$ & $\begin{array}{l}\text { 4D10-17, } \\
\text { 4E9, 4E11, } \\
\text { 4E18-19, } \\
\text { 4N10, 4N11 }\end{array}$ \\
\hline 3 & $\begin{array}{l}\text { Integrating - } \\
\text { Cross- } \\
\text { Functional }\end{array}$ & $\begin{array}{l}\mathrm{H} 5, \mathrm{H} 11, \\
\mathrm{I11}, \mathrm{J} 10, \\
\mathrm{~K} 12-18\end{array}$ & $\begin{array}{l}\text { T11, U2, } \\
\text { U3, U4*, } \\
\text { U6*, U7- } \\
19\end{array}$ & $\begin{array}{l}2 \mathrm{E} 5,2 \mathrm{E} 11, \\
2 \mathrm{E} 18,2 \mathrm{~F} 5, \\
2 \mathrm{~F} 11-18, \\
2 \mathrm{G} 5,2 \mathrm{G} 11\end{array}$ & $\begin{array}{l}2 \mathrm{P} 4^{*}, 2 \mathrm{P} 6 \\
2 \mathrm{P} 11,2 \mathrm{P} 17 \\
2 \mathrm{Q} 11,2 \mathrm{Q} 17 \\
2 \mathrm{Q} 18\end{array}$ & $\begin{array}{l}3 \mathrm{C} 5,3 \mathrm{C} 11- \\
\text { 18, 3D11, } \\
3 \mathrm{D} 18\end{array}$ & $\begin{array}{l}\text { 3J5, 3J7, 3J8, } \\
\text { 3J11, 4B5, } \\
\text { 4B11 }\end{array}$ & $\begin{array}{l}\text { 3P11, 3P17, } \\
3 \mathrm{Q} 5,3 \mathrm{Q} 11- \\
\text { 16, 3R11, } \\
\text { 3R18, 4C10- } \\
11,4 \mathrm{C} 17\end{array}$ & $\begin{array}{l}4 \mathrm{~A} 11, \\
4 \mathrm{~A} 18, \\
4 \mathrm{~B} 11-17, \\
4 \mathrm{C} 11, \\
4 \mathrm{C} 17,4 \mathrm{C} 18\end{array}$ \\
\hline
\end{tabular}

Sources: (Vakulenko I. and Saher L., 2021) 
The most relevant processes were as follows:

Stage I:

- developing a vision of a smart grid;

- development of IT infrastructure strategy for a smart grid;

- evaluation of the usefulness of the project;

- testing of devices and technologies;

- formation of value chains.

Stage II:

- development of a business plan;

- coordination of investments with the vision of budget formation;

- approval of the concept and formation of the project team;

- development of approaches to the implementation of GIS and RAM;

- pilot business processes, tactical investments in IT infrastructure;

- testing of technologies of interaction with clients.

Stage III:

- integration of smart grid strategy into corporate strategy;

- reaching a consensus with regulators:

- formation of a balanced system of indicators of a smart grid;

- coordination of business processes of the smart grid with the IT infrastructure;

- CBM development, RAM integration;

- involvement of customers in DR support (demand response).

Stage IV:

- involvement of external stakeholders in the implementation of a smart grid;

- optimization of business processes through IT infrastructure;

- the beginning of scaling of distributed energy generation;

- tariff formation based on analytics;

- modeling and optimization of portfolio expansion;

- formation of preconditions for integration into the higher-level network.

Stage $V$ :

- formation of the general strategy of expansion based on a smart grid;

- support of new enterprises (business projects) due to organizational changes;

- optimized regulatory policy;

- optimization of the use of assets by participants in the supply chain.

An organizational scheme of stakeholder interaction in smart grid projects is built for specific processes, as shown in Fig. 1.

According to fig. 1, building a smart grid involves many stakeholders at each stage of the project. However, some stakeholders are engaged in a significant number of processes in several stages. At the same time, others play a limited role in terms of activity and continuity of interaction with other participants in the process. The organizational scheme of stakeholder interaction in smart grid development allows identifying the stakeholders involved at each stage and in each function of smart grid development.

Below are some excerpts from the organizational scheme of stakeholder interaction. These fragments cannot be considered a detailed scheme. They are given in this article to demonstrate the principle proposed to be applied to the scheme's development. There is a difference in the fragments shown in Figure 1 and Figures 2-6. Figure 1 shows the key processes and stakeholders involved. This fragment is closest to the form of the final organizational scheme. Instead, Figures 2-6 contain elements that show at what stage stakeholders are involved. Such fragments do not lead to what processes stakeholders are 
engaged in. But these fragments of the organization scheme track the activity and time when stakeholders interact.

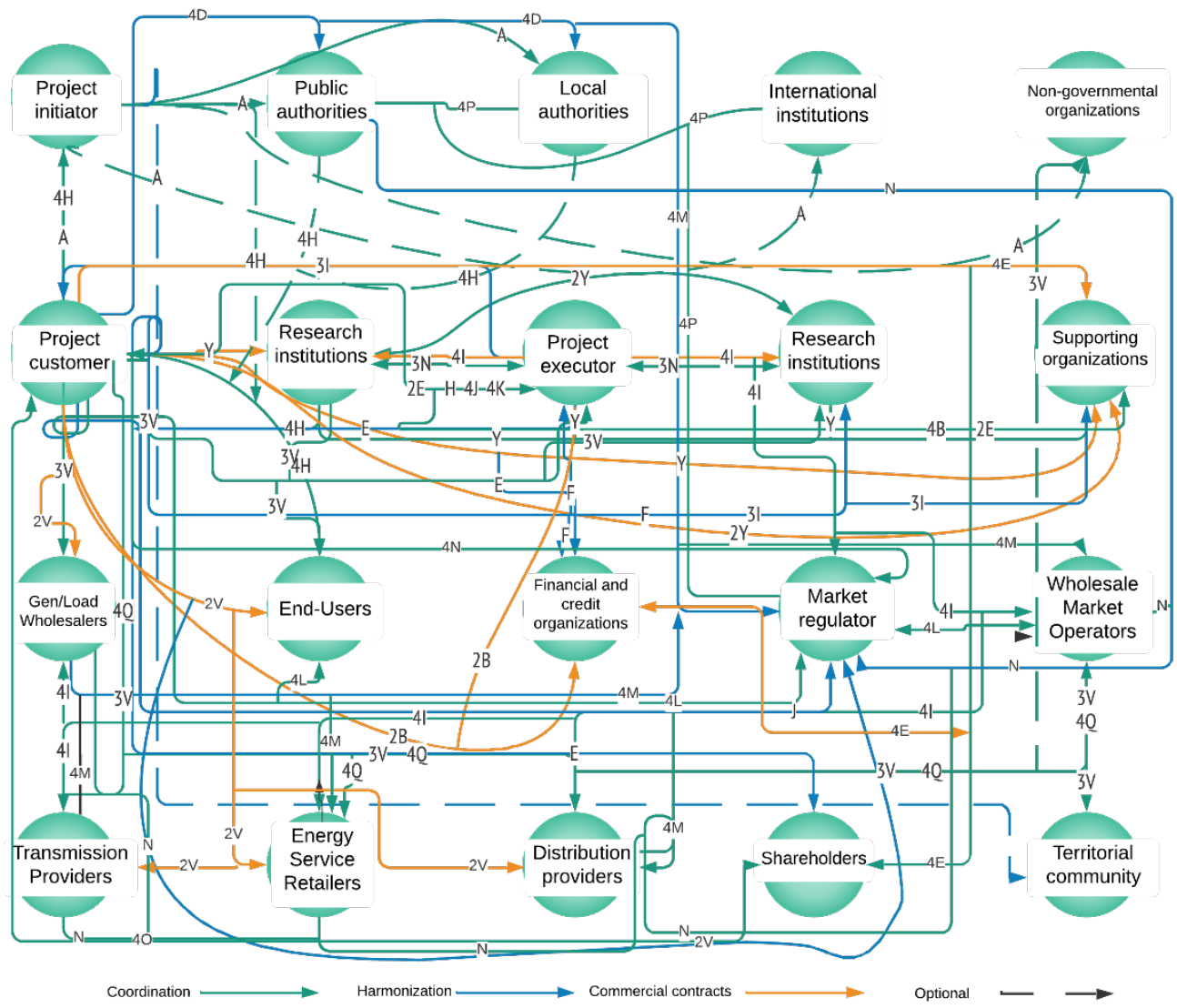

Figure 1. Organizational scheme of stakeholder interaction (fragment)

Sources: developed by the authors

The organizational scheme of stakeholders' participation in building a smart grid allows forming mechanisms for regulating their interaction. Among the tools that need further detail in the organizational chart of the interaction of stakeholders are the following.

Coordination. In this research, stakeholders' coordination is mutually agreed upon to implement individual processes of building a smart grid or project implementation. In this case, coordination involves voluntary activities not regulated by regulations and legal acts, and other mandatory types of documentation. Therefore, it provides a wide range of ways for stakeholders to interact. The optimal form of interaction is vital because it allows developing mechanisms to control building a smart grid. Much of the potential for facilitating the modernization of the energy sector through the deployment of smart grids, which does not require significant financial resources given its organizational nature, is concentrated in coordinating the actions of stakeholders. 
Harmonization is a type of coordination that is regulated by regulations and makes specific actions mandatory.

Commercial contracts in this study are all forms of interaction of stakeholders on a commercial basis.

The processes marked in Fig. 1 dotted lines are mandatory only for specific categories of smart grid projects.

The visualization in Fig. 1 shows authorities, project executors, financial and credit organizations, market regulators, customer or project customers, energy generating, transport and distribution companies, supporting organizations and enterprises (suppliers of goods and services), final consumers of energy resources are active participants in the process of building a smart grid. They perform a significant number of functions in developing, implementing, and maintaining smart grid projects.

The consolidation of the scheme allows identifying key stakeholders and the most relevant processes, which is vital for achieving high-quality scientific results to identify relationships and interdependencies in a complex system of organization, support, and support of energy system transformation through implementation.

The organizational scheme of stakeholder interaction allows to improve the mechanisms of their interaction during the implementation of smart grid projects at each stage: from the initiation of the idea, development of project documentation to the implementation and maintenance of a functioning smart grid. The organizational scheme can be helpful to implement the measures provided in a smart grid's development roadmap.

Figure 2 shows a simplified scheme of stakeholder interaction: a fragment of a detailed scheme using the coding explained above, which allows determining the stakeholders' relationships in implementing specific business processes. A simplified scheme shows the main directions of stakeholder interaction. smart grid.

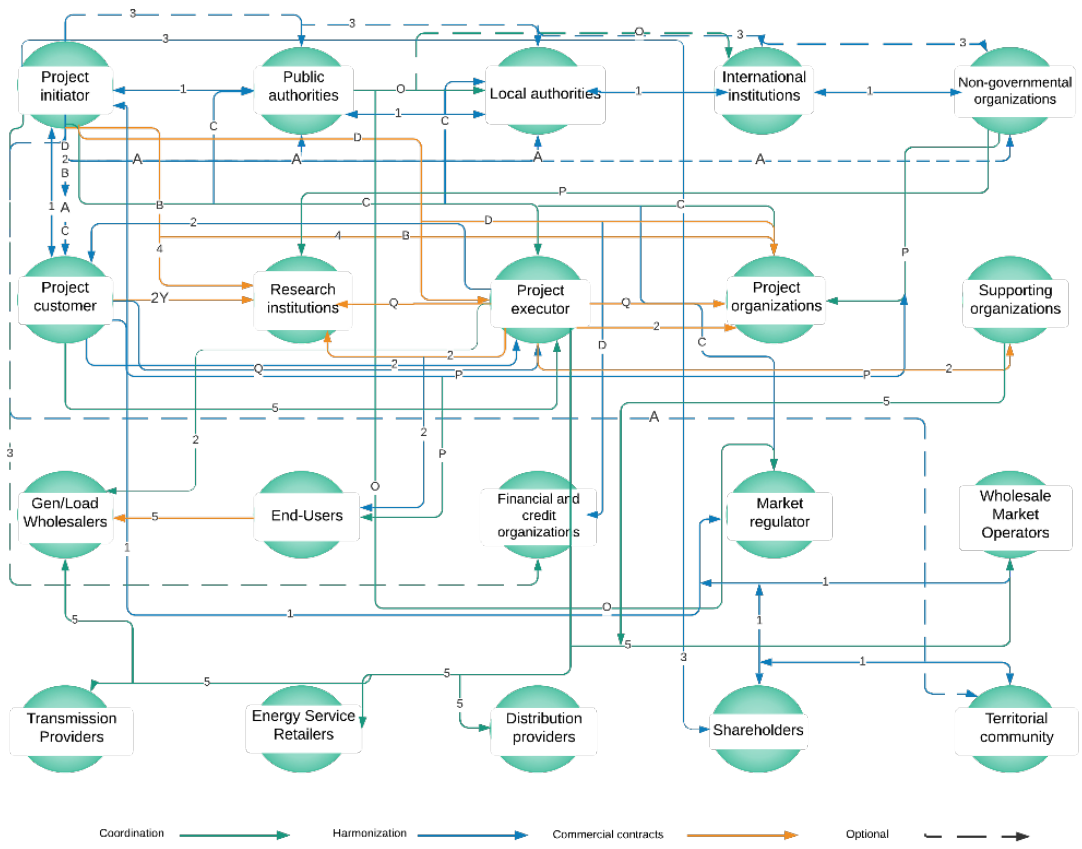

Figure 2. Organizational scheme of stakeholder interaction. Stage 1 (fragment) Sources: developed by the authors 
Symbols in Figure 2:

1 - developing a vision of a smart grid;

2 - development of IT infrastructure strategy for a smart grid;

3 - evaluation of the project's usefulness;

4 - testing of devices and technologies;

5 - formation of value chains.

At this stage, the interaction of stakeholders is focused on addressing strategic issues of developing the future smart grid and coordinating the interests of the most influential stakeholders at this stage: the initiator and customer of the project, public authorities, and local governments as well as energy market representatives.

Similar simplified visualizations for other stages are shown in Figures 2-6.

Figure 3 shows a simplified scheme of stakeholder interaction, which clarifies the features of the implementation of smart grid projects in the context of stakeholder interaction.

Symbols in Figure 3:

1 -development of a business plan;

2 - coordination of investments with the vision of budget formation;

3 - approval of the concept and shape of the project team;

4 - development of approaches to the implementation of GIS and RAM;

5 - pilot business processes, tactical investments in IT infrastructure;

6 - testing of technologies of interaction with clients.

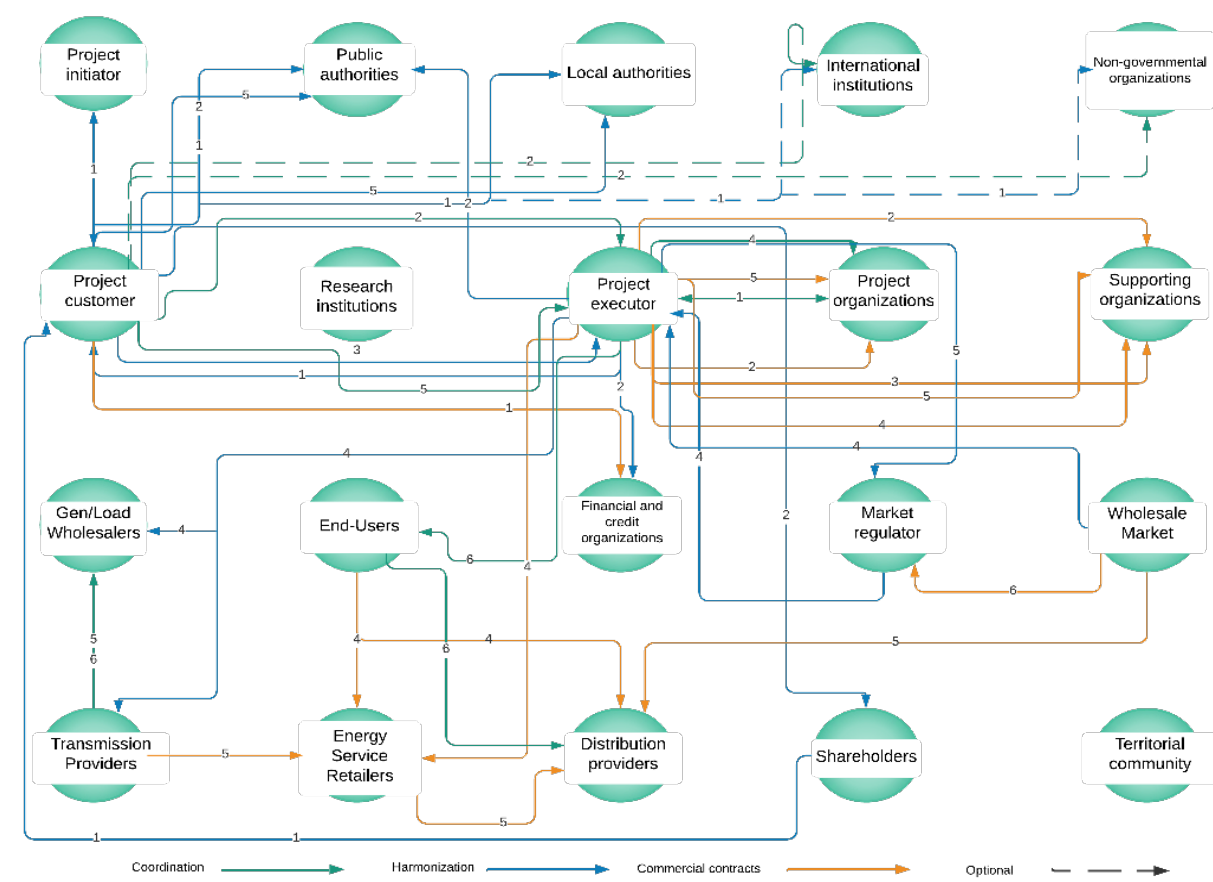

Figure 3. Organizational scheme of stakeholder interaction. Stage 2 (fragment) Sources: developed by the authors 
Figure 4 shows a simplified scheme of stakeholder interaction in the third stage of the modified smart grid maturity model, which demonstrates the shift of focus to the internal processes of key stakeholders (customer and project executor). Symbols in Figure 4:

1 - integration of smart grid strategy into corporate strategy;

2 - reaching a consensus with regulators;

3 - formation of a balanced system of indicators of a smart grid;

4 - coordination of business processes of the smart grid with the IT infrastructure;

5 - CBM development, RAM integration; 6 - involvement of customers in DR support (demand response).

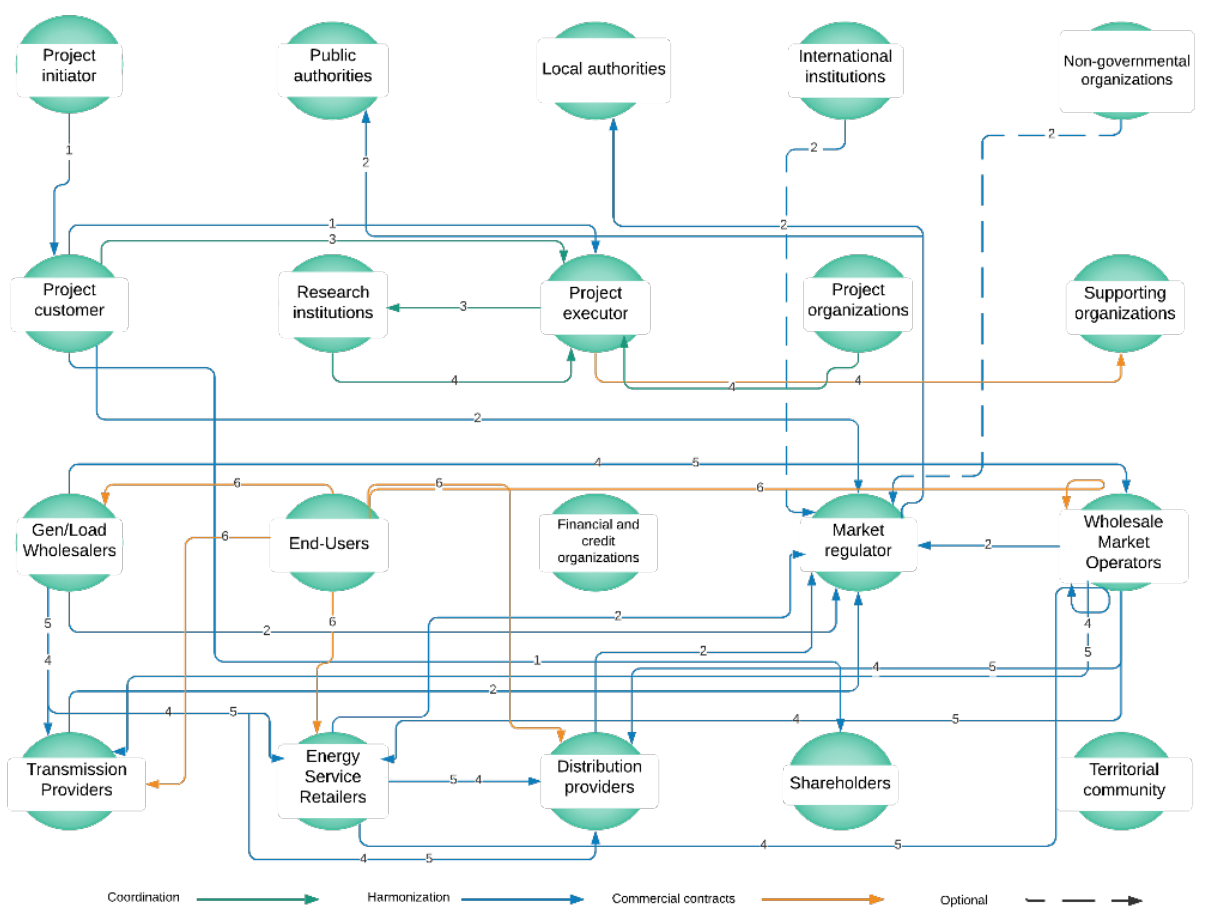

Figure 4. Organizational scheme of stakeholder interaction. Stage 3 (fragment) Sources: developed by the authors

Figure 5 shows a simplified scheme of stakeholder interaction at the fourth stage of the modified smart grid maturity model. The interaction between the energy sector and external stakeholders is intensified to realize the accumulated potential of scaling the smart grid. Symbols in Figure 5:

1 - involvement of external stakeholders in the implementation of a smart grid;

2 - optimization of business processes through IT infrastructure;

3 - the beginning of scaling of distributed energy generation;

4 - tariff formation based on analytics;

5 - modeling and optimization of portfolio expansion;

6 - formation of preconditions for integration into the higher-level network. 
l., Vakulenko, M., Fritsak, P. Fisunenko. An Organizational Scheme for Scaling Innovative Energy Projects. Smart Grids Case

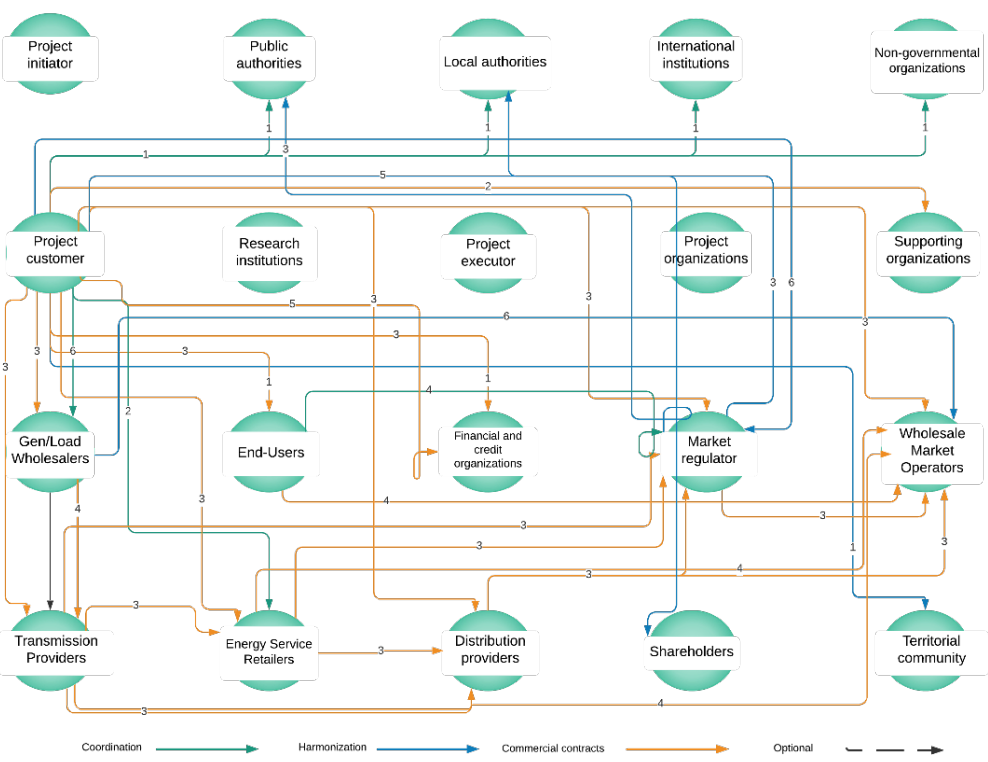

Figure 5. Organizational and communication scheme of stakeholder interaction. Stage 4 (fragment)

Sources: developed by the authors

Figure 6 shows a simplified scheme of stakeholder interaction.

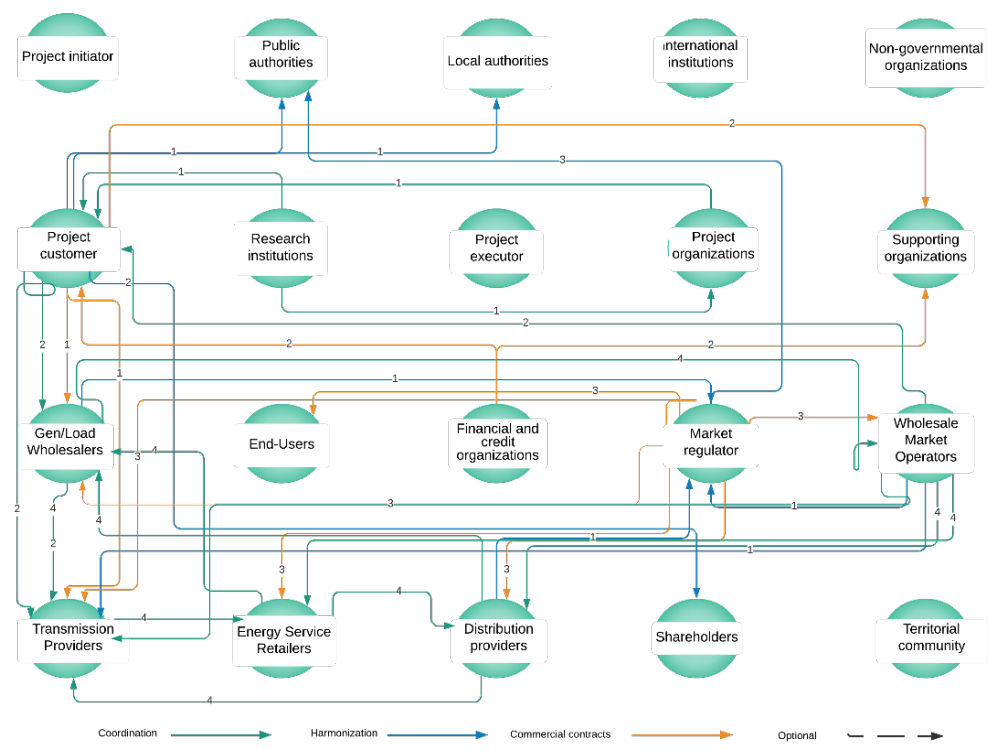

Figure 6 - Organizational scheme of stakeholder interaction. Step 5 (fragment) 
Symbols in Figure 6, which demonstrates the peculiarities of stakeholder cooperation at the creation and commercialization of a globally integrated energy network, which forms the preconditions for the transition to an integrated energy-centric economy model:

1 - formation of the general strategy of expansion based on a smart grid;

2 - support of new enterprises (business projects) due to organizational changes;

3 - optimized regulatory policy;

4 - optimization of the use of assets by participants in the supply chain.

Applying a modified smart grid maturity model allows creating tools for enhancing stakeholder interaction, creating favorable conditions for scaling smart grid projects, and tracing the change of motives and behavioral patterns of stakeholder cooperation.

Conclusions. The analysis of the existing smart grids' comprehensive assessment systems allows shaping a set of processes necessary for implementing innovative smart grids projects effectively. As a result of the systematization of these processes, it is possible to supplement the smart grid maturity model (based on the IBM Smart Grid Maturity Model). Complementing this model with a list of key stakeholders in implementing smart grid innovative projects forming the basis for creating an organizational scheme of their interaction at different stages of smart grid development, from project development to its implementation, maintenance and scaling. Although it is not an independent tool to stimulate smart grids, the organizational scheme can be used as an energy policy development and implementation element. This research does not provide a final organizational scheme but demonstrates the principles of its design. This paper presents the intermediate results of the study of energy policy implementation mechanisms, precisely designing and scaling innovative projects in the energy sector through better interaction between stakeholders and breaking down barriers between them. Thus, this study's results help activate latent reserves in the development of smart grids.

Author Contributions: conceptualization, I.V. and M.F.; methodology, I.V., validation, I.V., P.F. and M.F.; investigation, I.V.; resources, I.V.; writing-original draft preparation, I.V.; writing-review and editing, I.V.; visualization, I.V.

Funding: This work was supported by the Ministry of Education and Science of Ukraine (0119U100766 "The Optimization Model of Smart and Secure Energy Grids Building: An Innovative Technologies of Enterprises and Regions Ecologisation"; "Green investing: cointegration model of transmission ESG effects in the chain "green brand of Ukraine - social responsibility of business" (0121U100468, Ministry of Education and Science of Ukraine), 2021-2023 years.

\section{References}

Adinyira, E., Kwofie, T. E., \& Quarcoo, F. (2018). Stakeholder requirements for building energy efficiency in mass housing delivery: The house of quality approach. Environment, Development and Sustainability, 20(3), 1115-1131. [CrossRef]

Afshari, H., Farel, R., \& Peng, Q. (2018). Challenges of value creation in eco-industrial parks (EIPs): A stakeholder perspective for optimizing energy exchanges. Resources, Conservation and Recycling, 139, 315-325. [CrossRef]

Alvial-Palavicino, C., Garrido-Echeverría, N., Jiménez-Estévez, G., Reyes, L., \& Palma-Behnke, R. (2011). A methodology for community engagement in the introduction of renewable based smart microgrid. Energy for Sustainable Development, 15(3), 314 323. [CrossRef]

Baldwin, E. (2019). Exploring how institutional arrangements shape stakeholder influence on policy decisions: A comparative analysis in the energy sector. Public Administration Review, 79(2), 246-255. [CrossRef]

Bourdin S., Nadou F., Raulin F. (2019). Les collectivités locales comme acteurs intermédiaires de la territorialisation de la transition énergétique : l'exemple de la méthanisation. Géographie, économie, société, 21, 273-293. [CrossRef]

Chygryn, O., Pimonenko, T., Luylyov, O., \& Goncharova, A. (2018). Green bonds like the incentive instrument for cleaner production at the government and corporate levels: Experience from EU to Ukraine. Journal of Environmental Management and Tourism, 9(7), 1443-1456. [CrossRef]

Curtis, P. G., Hanias, M., Kourtis, E., \& Kourtis, M. (2020). Data envelopment analysis (DEA) and financial ratios: A prostakeholders' view of performance measurement for sustainable value creation of the wind energy. International Journal of 


\section{l., Vakulenko, M., Fritsak, P. Fisunenko. An Organizational Scheme for Scaling Innovative Energy Projects. Smart Grids Case}

Economics and Business Administration, 8(2), 326-350. [CrossRef]

Danielson, M., Ekenberg, L., \& Komendantova, N. (2018). A multi-stakeholder approach to energy transition policy formation in Jordan. Lecture Notes in Business Information Processing. [CrossRef]

Dias, L. C., Antunes, C. H., Dantas, G., de Castro, N., \& Zamboni, L. (2018). A multi-criteria approach to sort and rank policies based on delphi qualitative assessments and ELECTRE TRI: The case of smart grids in brazil. Omega (United Kingdom), 76, 100111. [CrossRef]

Ehsan, S., Nazir, M. S., Nurunnabi, M., Khan, Q. R., Tahir, S., \& Ahmed, I. (2018). A multimethod approach to assess and measure corporate social responsibility disclosure and practices in a developing economy. Sustainability (Switzerland), 10(8). [CrossRef]

Elmustapha, H., Hoppe, T., \& Bressers, H. (2018). Understanding stakeholders' views and the influence of the socio-cultural dimension on the adoption of solar energy technology in lebanon. Sustainability (Switzerland), 10(2). [CrossRef]

European Technology Platform Smart Grids: Vision and Strategy for Europe's Electricity Networks of the Future (2006) Directorate-General for Research Sustainable Energy Systems, 2006. Retrieved from https://orbit.dtu.dk/en/publications/vision-andstrategy-for-europes-electricity-networks-of-the-futur.

Fotis, P., \& Polemis, M. (2018). Sustainable development, environmental policy and renewable energy use: A dynamic panel data approach. Sustainable Development, 26(6), 726-740. [CrossRef]

Gao, L., \& Zhao, Z. -. (2020). The evolutionary game of stakeholders' coordination mechanism of new energy power construction PPP project: A china case. Sustainability (Switzerland), 12(3). [CrossRef]

Gölz, S., \& Wedderhoff, O. (2018). Explaining regional acceptance of the german energy transition by including trust in stakeholders and perception of fairness as socio-institutional factors. Energy Research and Social Science, 43, 96-108. [CrossRef] Graff, M., Carley, S., \& Konisky, D. M. (2018). Stakeholder perceptions of the united states energy transition: Local-level dynamics and community responses to national politics and policy. Energy Research and Social Science, 43, 144-157. [CrossRef]

Guðlaugsson, B., Fazeli, R., Gunnarsdóttir, I., Davidsdottir, B., \& Stefansson, G. (2020). Classification of stakeholders of sustainable energy development in iceland: Utilizing a power-interest matrix and fuzzy logic theory. Energy for Sustainable Development, 57, 168-188. [CrossRef]

Gunnarsdóttir, I., Davíðsdóttir, B., Worrell, E., \& Sigurgeirsdottir, S. (2021). It is best to ask: Designing a stakeholder-centric approach to selecting sustainable energy development indicators. Energy Research and Social Science, 74 [CrossRef]

Hilorme, T., Nazarenko, I., Okulicz-Kozaryn, W., Getman, O., Drobyazko, S. (2018). Innovative model of economic behavior of agents in the sphere of energy conservation. Academy of Entrepreneurship Journal, 9 (1), 1-7. [Google Scholar]

Hilorme, T., Sokolova, L., Portna, O., Lysiak, L., \& Boretskaya, N. (2019). Smart grid concept as a perspective for the development of Ukrainian energy platform. IBIMA Business Review, 2019 [CrossRef]

Hilorme, T., Tkach, K., Dorenskyi, O., Katerna, O., \& Durmanov, A. (2019). Decision making model of introducing energy-saving technologies based on the analytic hierarchy process. Journal of Management Information and Decision Sciences, (4), 489494. [Google Scholar]

Hoolohan, C., Larkin, A., McLachlan, C., Falconer, R., Soutar, I., Suckling, J., . . Yu, D. (2018). Engaging stakeholders in research to address water-energy-food (WEF) nexus challenges. Sustainability Science, 13(5), 1415-1426. [CrossRef]

Jia, L., Qian, Q. K., Meijer, F., \& Visscher, H. (2020). Stakeholders' risk perception: A perspective for proactive risk management in residential building energy retrofits in china. Sustainability (Switzerland), 12(7) [CrossRef]

Joensuu, T., Norvasuo, M., \& Edelman, H. (2020). Stakeholders' interests in developing an energy ecosystem for the superblock-case hiedanranta. Sustainability (Switzerland), 12(1) [CrossRef]

Kester J. (2016). Conducting a smarter grid: Reflecting on the power and security behind smart grids with foucault. Smart Grids from a Global Perspective, 197-213. Retrieved from https://www.researchgate.net/publication/314931978_Conducting_a_ Smarter_Grid_Reflecting_on_the_Power_and_Security_Behind_Smart_Grids_with_Foucault. [Google Scholar]

Li, H. X., Patel, D., Al-Hussein, M., Yu, H., \& Gül, M. (2018). Stakeholder studies and the social networks of NetZero energy homes (NZEHs). Sustainable Cities and Society, 38, 9-17. [CrossRef]

Lieonov S., Pavlyk A. (2019). Collaboration drivers on renewable energy. European energy collaboration: modern smart specialization strategies : monograph / edited by Vasilyeva T. A., Kolosok S. I. Szczecin: Centre of Sociological Research. 179 p. [Google Scholar]

Liu, H. -., You, X. -., Xue, Y. -., \& Luan, X. (2017). Exploring critical factors influencing the diffusion of electric vehicles in China: A multi-stakeholder perspective. Research in Transportation Economics, 66, 46-58. [CrossRef]

Lyulyov, O., Vakulenko, I., Pimonenko, T., Kwilinski, A., Dzwigol, H., \& Dzwigol-Barosz, M. (2021). Comprehensive assessment of smart grids: Is there a universal approach? Energies, 14(12) [CrossRef]

Maqbool, R., Deng, X., \& Rashid, Y. (2020). Stakeholders' satisfaction as a key determinant of critical success factors in renewable energy projects. Energy, Sustainability and Society, 10(1). [CrossRef]

Mentel, G., Vasilyeva, T., Samusevych, Y., Vysochyna, A., Karbach, R., \& Streimikis, J. (2020). The evaluation of economic, environmental and energy security: Composite approach. International Journal of Global Environmental Issues, 19(1-3), 177195. [Google Scholar]

Nasr, A. K., Kashan, M. K., Maleki, A., Jafari, N., \& Hashemi, H. (2020). Assessment of barriers to renewable energy development using stakeholders approach. Entrepreneurship and Sustainability Issues, 7(3), 2526-2541. [CrossRef] 


\section{l., Vakulenko, M., Fritsak, P. Fisunenko. An Organizational Scheme for Scaling Innovative Energy Projects. Smart Grids Case}

Neves, D., Baptista, P., Simões, M., Silva, C. A., \& Figueira, J. R. (2018). Designing a municipal sustainable energy strategy using multi-criteria decision analysis. Journal of Cleaner Production, 176, 251-260. [CrossRef]

Nikas, A., Stavrakas, V., Arsenopoulos, A., Doukas, H., Antosiewicz, M., Witajewski-Baltvilks, J., \& Flamos, A. (2020). Barriers to and consequences of a solar-based energy transition in greece. Environmental Innovation and Societal Transitions, 35, 383-399. [CrossRef]

Olkkonen, L., Korjonen-Kuusipuro, K., \& Grönberg, I. (2017). Redefining a stakeholder relation: Finnish energy "prosumers" as co-producers. Environmental Innovation and Societal Transitions, 24, 57-66. [CrossRef]

Ouhajou, N., Loibl, W., Fenz, S., \& Tjoa, A. M. (2017). Stakeholder-oriented energy planning support in cities. Sustainable Cities and Society, 28, 482-492. [CrossRefl

Pimonenko, T., Prokopenko, O., \& Dado, J. (2017). Net zero house: EU experience in Ukrainian conditions. International Journal of Ecological Economics and Statistics, 38(4), 46-57. [Google Scholar]

Solman, H., Smits, M., van Vliet, B., \& Bush, S. (2021). Co-production in the wind energy sector: A systematic literature review of public engagement beyond invited stakeholder participation. Energy Research and Social Science, 72 [CrossRef]

Späth, L., \& Scolobig, A. (2017). Stakeholder empowerment through participatory planning practices: The case of electricity transmission lines in France and Norway. Energy Research and Social Science, 23, 189-198. [CrossRef]

Sun, Y., Li, Y., Cai, B. -., \& Li, Q. (2020). Comparing the explicit and implicit attitudes of energy stakeholders and the public towards carbon capture and storage. Journal of Cleaner Production, 254 [CrossRef]

Sušnik, J., Chew, C., Domingo, X., Mereu, S., Trabucco, A., Evans, B., . . Brouwer, F. (2018). Multi-stakeholder development of a serious game to explore the water-energy-food-land-climate nexus: The SIM4NEXUS approach. Water (Switzerland), 10(2). [CrossRef]

Tang, S., \& Demeritt, D. (2018). Climate change and mandatory carbon reporting: Impacts on business process and performance. Business Strategy and the Environment, 27(4), 437-455. [CrossRef]

Tetiana, H., Chernysh, O., Levchenko, A., Semenenko, O., \& Mykhailichenko, H. (2019). Strategic solutions for the implementation of innovation projects. Academy of Strategic Management Journal, 18(Special Issue 1), 1-6. [Google Scholar]

Vakulenko, I., Saher, L., Syhyda, L., Kolosok, S., \& Yevdokymova, A. (2021). The first step in removing communication and organizational barriers to stakeholders' interaction in smart grids: $A$ theoretical approach. Paper presented at the E3S Web of Conferences, , 234 [CrossRef]

Vasylieva, T., Lyulyov, O., Bilan, Y., \& Streimikiene, D. (2019). Sustainable economic development and greenhouse gas emissions: The dynamic impact of renewable energy consumption, GDP, and corruption. Energies, 12(17) [CrossRef]

Vysochyna, A., Stoyanets, N., Mentel, G., \& Olejarz, T. (2020). Environmental determinants of a country's food security in shortterm and long-term perspectives. Sustainability (Switzerland), 12(10) [CrossRef]

White, D. D., Jones, J. L., Maciejewski, R., Aggarwal, R., \& Mascaro, G. (2017). Stakeholder analysis for the food-energy-water nexus in Phoenix, Arizona: Implications for nexus governance. Sustainability (Switzerland), 9(12) [CrossRef]

Zedan, S., \& Miller, W. (2018). Quantifying stakeholders' influence on energy efficiency of housing: Development and application of a four-step methodology. Construction Management and Economics, 36(7), 375-393. [CrossRef]

Ігор Вакуленко, к.е.н., Сумський державний університет, Україна

Максим Фріцак, Швейцарський федеральний технологічний інститут, Німеччина

Павло Фісуненко, к.е.н., доцент, Придніпровська державна академія будівництва та архітектури, Україна

Організаційна схема масштабування інноваційних енергетичних проектів на прикладі розумних енергомереж

Перехід до вуглецево-нейтральної економіки, який здійснюється зараз багатьма країнами, потребує використання глибоких перетворень в енергетиці, у тому числі застосування інноваційних технологій. Розумні енергомережі $є$ втіленням інноваційного розвитку енергетики. Вони передбачають широке застосування сучасних передових технологій у багатьох напрямках, від виробництва енергії до створення захищеної інформаційної системи. Успішні локальні проекти потребують допомоги для їх поширення на глобальний рівень. Проте така допомога не має бути обмежена державним втручанням та адміністративними методами. Необхідний саморегульований ринковий механізм для масштабування таких проектів. Деякі країни мають проторений шлях для поширення інновацій. Проте швидкість поширення інновацій різна у кожній країні. Це залежить від низки унікальних умов, які є у тій чи іншій країні. Навряд чи існує універсальний спосіб швидкого поширення інновацій, який буде ефективним для застосування у кожній країні. Проте має існувати механізм, де усі стейкхолдери організовано працюють над поширенням інновацій, що прискорює цей процес. Метою даної статті є розроблення підходу до формування механізму взаємодії стейкхолдерів у енергетичній галузі економіки на основі створення організаційної схеми їх взаємодії. Для досягнення мети було використано результати компаративного аналізу комплексних систем оцінювання розумних енергомереж, що дозволило алгоритмізувати процеси їх створення, розвитку та супроводу як основи для подальшого масштабування успішних проектів. Визначений алгоритм $€$ модифікацією моделі зрілості розумної енергомережі, розробленої компанією IBM. Окрім того, було здійснено ґрунтовний аналіз наукових публікацій у сфері реалізації інноваційних проектів у енергетичному секторі, присвячених впровадженню розумних енергомереж. Візуалізацію запропонованого підходу до впорядкування діяльності стейкхолдерів здійснено на основі результатів дослідження, спрямованого на пошук шляхів подолання організаційно-комунікаційних бар'єрів між стейкхолдерами, де здійснено 
l., Vakulenko, M., Fritsak, P. Fisunenko. An Organizational Scheme for Scaling Innovative Energy Projects. Smart Grids Case

кодування процесів реалізації проектів розумних енергомереж. Наукові результати, висвітлені у даній статті, є проміжним етапом у дослідженні механізмів підвищення ефективності реалізації та масштабування інноваційних енергоефективних проектів, зокрема з розбудови розумних енергомереж, на основі активізації латентних драйверів. Такими драйверами розглядаються організаційно-комунікаційні інструменти.

Ключові слова: організаційна схема, енергетика, розумні енергомережі, стейкхолдери, модель зрілості. 